\title{
On two closely related species of Synagelides Strand, 1906 (Aranei: Salticidae) from the eastern Palaearctic
}

\section{О двух родственных видах рода Synagelides Strand, 1906 (Aranei: Salticidae) из восточной Палеарктики}

\author{
Mikhail M. Omelko ${ }^{1,2}$, Alexander A. Fomichev ${ }^{3}$ \\ М.М. Омелько ${ }^{1,2}$, А.А. Фомичев ${ }^{3}$
}

\footnotetext{
${ }^{1}$ Federal Scientific Center of East Asia Terrestrial Biodiversity, Far Eastern Branch, Russian Academy of Sciences, Vladivostok 690022, Russia. E-mail: omelkom@gmail.com

${ }^{2}$ Far Eastern Federal University, Laboratory of ecology and evolutionary biology of aquatic organisms (LEEBAO), School of Natural Sciences, Vladivostok 690091, Russia.

${ }^{3}$ Altai State University, Lenina Pr., 61, Barnaul, RF-656049, Russia. E-mail: a.fomichov@mail.ru

${ }^{1}$ Федеральный научный центр Биоразнообразия наземной биоты Восточной Азии ДВО РАН, Владивосток 690022, Россия

2 Дальневосточный Федеральный Университет, Лаборатория экологии и эволюционной биологии водных организмов (ЛЭБВО), Школа Естественных Наук, Владивосток 690091, Россия.

3 Алтайский государственный университет, Проспект Ленина, 61, Барнаул, 656049, Россия.
}

KEY WORDS: Araneae, the Far East, redescription, Sikhote-Alin Mt. Range.

КЛЮЧЕВЫЕ СЛОВА: Araneae, Дальний Восток, переописание, хребет Сихотэ-Алинь.

ABSTRACT. The unknown male of Synagelides zhilcovae Prószyński, 1979 is described for the first time, and the female is redescribed. The closely related species $S$. agoriformis Strand, 1906 is redescribed based on newly collected material. Both species are widespread in East Asia.

How to cite this paper: Omelko M.M., Fomichev A.A. 2021. On two closely related species of Synagelides Strand, 1906 (Aranei: Salticidae) from the eastern Palaearctic // Arthropoda Selecta. Vol.30. No.1. P.95-104. doi: 10.15298/arthsel.30.1.08

РЕЗЮМЕ. Для вида Synagelides zhilcovae Prószyński, 1979 впервые описан самец, а самка переописана. На основании нового материала переописан родственный вид S. agoriformis Strand, 1906. Оба вида имеют широкое распространение в Восточной Азии.

\section{Introduction}

Synagelides Strand, 1906 is a large ant-mimicking genus of Salticidae accounting for 50 species that are distributed in South and East Asia, and the Oriental Region [WSC, 2020], predominantly in the tropics and subtropics [Kanesharatnam, Benjamin, 2020]. Most described species are known from Nepal and eastern/ southern provinces of China [Logunov, Hereward, 2006; Song et al., 1999]. Over a half of Synagelides species are known from a single sex and 14 of them were described from females [WSC, 2020]. This problem is complicated by a strong variation of the copulatory organs in Synagelides, which is a common phenomenon in the Salticidae [Logunov, Hereward, 2006]. It is worth mentioning that some species of Synagelides should be transferred to Agorius Thorell, 1877 or even that these two genera could be synonymous [Logunov, 2017; Logunov, Hereward, 2006]. Only two Synagelides species are known to occur in the Russian Far East: $S$. agoriformis Strand, 1906 and S. zhilcovae Prószyński, 1979. S. agoriformis is the type species of the genus, also known from China, Korea and Japan [WSC, 2020]. The second species has a similar range. In the Russian Far East, both species occur in the continental southern Far East and the southern Kurile Islands [Logunov, Marusik, 2001]. The male of $S$. zhilcovae remains formally undescribed, although it has been reported under the name of $S$. agoriformis several times (e.g., Prószyński, 1979: $\left.0^{7}\right)$; yet the females of both species are very similar. There are only sketchy drawings for both species and small-sized published photos of S. agoriformis [Chikuni, 1989; Kim, Kim, 2003; Ono, Ogata, 2018]. While studying the material collected from the Russian Far East, we have found several specimens of both sexes of $S$. agoriformis and $S$. zhilcovae. Later, we got an opportunity to examine more specimens of both species from different localities of the eastern Palaearctic. The aims of the present paper are (1) to provide the first description of the male of $S$. zhilcovae, (2) to redescribe $S$. agoriformis in detail, (3) to reliably diagnose both species, and (4) to clarify distribution of both species based on the new and literature-derived records. 

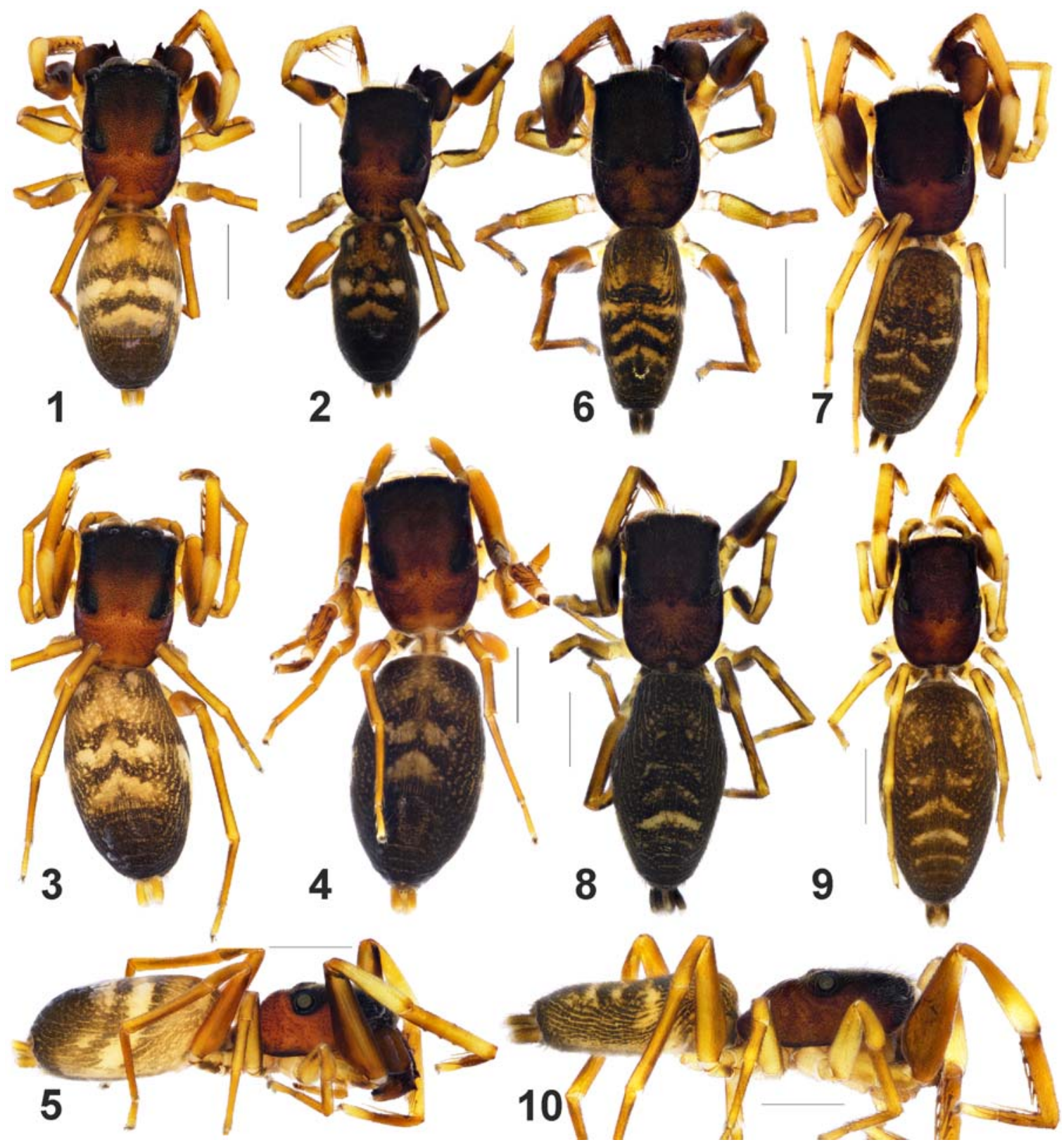

Figs 1-10. General appearance of Synagelides agoriformis Strand, 1906 (1-5) and S. zhilcovae Prószyński, 1979 (6-10): 1, 2, 6, 7 male, dorsal; 5, 10 - ditto, lateral view; 3, 4, 8, 9 - female, dorsal view. Specimens: 1, 3, 5- from Liaoning Prov. (China); 2, 4, 6, 8-10 from Maritime Territory (Russia); 7, 9 - from Shikotan Isl. (Russia). Scale bars: $1 \mathrm{~mm}$.

Рис. 1-10. Внешний вид Synagelides agoriformis Strand, 1906 (1-5) и S. zhilcovae Prószyński, 1979 (6-10): 1, 2, 6, 7 - caмец, вид дорсально; 5, 10 - тоже, вид сбоку; 3, 4, 8, 9 - самка, вид дорсальною Экземпляры: 1, 3, 5 - из провинции Ляонин (Китай); 2, 4, 6, 8-10 - из Приморского края (Россия); 7, 9 - с о. Шикотан (Россия). Масштаб 1 мм.

\section{Material and methods}

Specimens were photographed by means of a Nikon DSRi2 camera attached to a Nikon SMZ25 stereomicroscope at the Far Eastern Federal University, Vladivostok, Russia and Olympus DP74 camera attached to an Olympus SZX16 stereomicroscope at the Altai State University, Barnaul, Russia. Photographs were taken in dishes with soft white paper at the bottom, filled with alcohol. Digital images were mon- taged by using the Zerene Stacker software (http:// zerenesystems.com/cms/stacker). Epigynes were cleared in a $\mathrm{KOH} /$ water solution. All measurements are in millimeters. The examined material is shared between the Institute of Systematics and Ecology of Animals SB RAS, Novosibirsk, Russia (ISEA; curator: G.N. Azarkina), the Far Eastern Federal University (FEFU; curator: M.M. Omelko), the Manchester Museum, University of Manchester (MMUE; curator: Dmitri Logunov), and the Museum and Institute of Zoology 



Figs 11-14. Frontal view of carapace and prolateral view of leg I in the males of Synagelides agoriformis Strand, 1906 (11-12) and S. zhilcovae Prószyński, 1979 (13-14). Scale bars: $0.5 \mathrm{~mm}$.

Рис. 11-14. Вид спереди головогруди и пролатерально ноги I у самцов Synagelides agoriformis Strand, 1906 (11-12) и $S$. zhilcovae Prószyński, 1979 (13-14). Масштаб 0,5 мм.

in Warsaw, Poland (MIZW; curator Wioletta Wawer).

Terminology and abbreviations used in the text and figures follow Prószyński [1979], Bohdanowicz \& Prószyński [1987], Liu et al. [2017], Logunov [2017] and Lin \& Li [2020], with some modifications and additions. Eyes: AME anterior median eyes, PLE - posterior lateral eyes. Leg segments: $\mathrm{Fe}$ - femur, $\mathrm{Pt}$ - patella, $\mathrm{Mt}$ - metatarsus, $\mathrm{Ti}$ tibia, Ta - tarsus. Leg spination: $\mathrm{v}$ - ventral. Copulatory organs (Figs 15-17, 21, 25, 29-42): Ae - anterior edge of epigyne, Ag - anterior groove of epigyne pocket, Ao anterior outgrowth, $\mathrm{Cd}$ - copulatory duct, $\mathrm{Ct}$ - prolateral cymbial tooth, $\mathrm{Co}$ - copulatory opening, $\mathrm{Db}$ - dorsal branch, E - embolus, Ep — pocket of epigyne, Fa prolateral femoral apophysis, Fd - fertilization duct, Gd glandular duct, Le - lateral edge of epigyne, $\mathrm{Ma}$ - median apophysis, Mtp - membranous tegular peak, Pg — posterior groove of epigyne pocket, $\mathrm{Po}$ - posterior outgrowth, $\mathrm{Pp}$ posterior edge of epigyne pocket, RTA - retrolateral tibial apophysis, S - spermatheca, Sc - sclerotized curve of copulatory duct, $\mathrm{Sd}$ - sperm duct, $\mathrm{T}$ - tegulum, Ts tibial spine, $\mathrm{Vb}$ - ventral branch, $\mathrm{Wd}$ - widened part of copulatory ducts.

\section{Descriptions}

Synagelides agoriformis Strand, 1906 Figs $1-5,11-12,15-17,21-24,29-34,41$, Maps 1, 2.

Synagelides agoriformis Strand, in Bösenberg et Strand, 1906: $330\left(\begin{array}{l}(+) \\ +\end{array}\right)$.
Synagelides agoriformis: Bohdanowicz, 1979: 55, figs 1-8 $\left(\sigma^{\top}+\right)$; Bohdanowicz, Prószyński, 1987: 133, figs 268-279 ( $\left.\sigma^{7}+\right)$; Chikuni, 1989: 158, figs 52 ( $\left.\sigma^{\top} O\right)$; Namkung, 2002: 603, figs 43.47a-b ( $\sigma^{7}$ ) ; Ono et al., 2009: 588, figs 347-351 ( $\left.\sigma^{7}+\right)$.

For a complete list of taxonomic references see WSC [2020].

MATERIAL. CHINA: Liaoning Prov.: $4 \bigcirc^{\top} \sigma^{\top}, 3$ 90 (MMUE), Fengcheng city, Mt. Phoenix (c. $40^{\circ} 23^{\prime} \mathrm{N}, 124^{\circ} 05^{\prime} \mathrm{E}$ ), $280-550 \mathrm{~m}$ a.s.1., 16-18.10.2017, Yu.M. Marusik. - JAPAN: Osaka Pref:: 1 $\sigma^{7}$ (MMUE), Minoh City, 26.03.1977, Y. Nishikawa. — NORTH KOREA: Hamgyong Prov: 1 ( $\sigma^{\top}$ (MIZW), Kyongsong County, Ompho-ri, thickets and mixed forest above the stream, in the litter, under stones and on plants, 8-11.09.1966, C. Dziadosz, H. Szelegiewici; North Pyongan Prov.: 1 + (MIZW), Myohyang Mt., mixed forest, thickets, granite rocks, stones and wet litter, 19.06. 1965, M. Mroczkowski, A. Riedel. - RUSSIA: Maritime Territory: $1 \sigma^{7}, 1$ (MMUE), Khasanskii Dist., Leopard's Land national park, northern slope of El'duga river nr. branching off Griaznaya River, black fir forest, 26.08.2018, L.A. Trilikauskas; $2 \sigma^{7} \sigma^{7}$ (ISEA), same locality, downstream of Griaznaya River, nr. reserve's cordon, broadleaved (oak) forest, litter, 25-30.08.2018, L.A. Trilikauskas; $1 \sigma^{7}$ (FEFU), $1 \overbrace{}^{7}, 1$ (ISEA), Ussuriyskii Dist., nr.

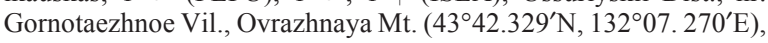
large-block scree in oak forest, $200 \mathrm{~m}$ a.s.1., 14.07.2019, A.A. Fomichev.

DIAGNOSIS. The species is most similar to S. zhilcovae, but both sexes can be easily distinguished by the following characters. The eye field in both sexes of $S$. agoriformis is black anteriorly and yellowish in its posterior part ( $v s$. entirely black in S. zhilcovae; cf. Figs 1-4 and 6-9). Transverse stripes on dorsum in both sexes are wide, round spots are usually well visible ( $v s$. narrow stripes, round spots small or absent; cf. Figs 1-4 and 6-9). Prolateral cymbial tooth $(C t)$ is small, with its tip being directed strictly posteriad (vs. large, with tip being directed dorso-posteriad; cf. 

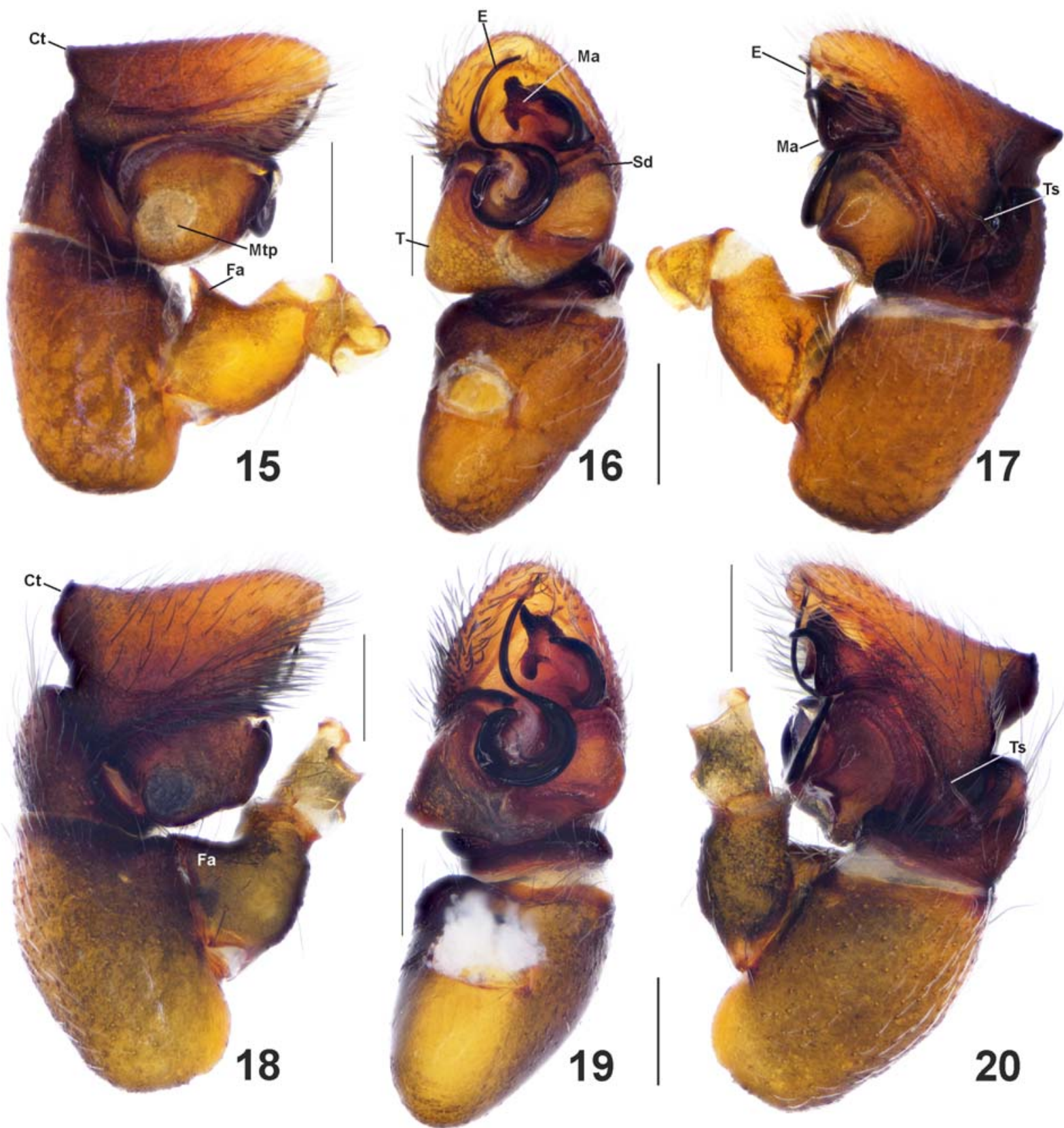

Figs 15-20. Male palps of Synagelides agoriformis Strand, 1906 (15-17) and S. zhilcovae Prószyński, 1979 (18-20): 15, 18 prolateral view; 16, 19 - ventral view; 17, 20 - retrolateral view. Scale bars: $0.25 \mathrm{~mm}$. Abbreviations: $\mathrm{Ct}$ - prolateral cymbium tooth, E embolus, $\mathrm{Fa}$ - prolateral femoral apophysis, $\mathrm{Ma}$ - median apophysis, Mtp — membranous tegular peak, $\mathrm{Sd}$ — sperm duct, $\mathrm{T}$ — tegulum, Ts - tibial spine.

Рис. 15-20. Пальпы самцов Synagelides agoriformis Strand, 1906 (15-17) и S. zhilcovae Prószyński, 1979 (18-20): 15, 18 — вид пролатерально; 16, 19 - вид вентрально; 17, 20 - вид ретролатерально. Масштаб 0,25 мм. Сокращения: $\mathrm{Ct}$ - пролатеральный зуб цимбиума, Е - эмболюс, $\mathrm{Fa}$ - пролатеральный отросток бедра, Ма — медиальный отросток, Мtр - мембранозный вырост тегулума, $\mathrm{Sd}$ - семенной проток, T - тегулум, Ts - шип голени.

Figs 15 and 18). Anterior outgrowth $(A o)$ of the dorsal branch of median apophysis is blunt, while the posterior one $(P o)$ triangular-conical (vs. Ao pointed and Po digitiform in S. zhilcovae; cf. Figs 21 and 25). The anterior edge of the epigyne $(A e)$ is U-shaped, often strongly rounded ( $v S$. Ae Vshaped; cf. Figs 29-32 and 35-38). Anterior grooves of the epyginal pocket $(A g)$ are comparatively small ( $v s$. large in $S$. zhilcovae; cf. Figs $29-32$ and 35-38). Widened parts $(W d)$ of the copulatory ducts $(C d)$ lie above the line joining posterior edges of the epigynal pockets $(P p)(v s . C d$ lie below the line joining $P p$ or they are crossed by the line; cf. Figs 31 and 37). Spermathecae $(S)$ are clearly visible in the intact epigyne ( $v s$. either poorly visible or invisible in S. zhilcovae; cf. Figs 29-32 and 35-38). Spermathecae $(S)$ are spaced apart from widened parts of the copulatory ducts $(W d$, see space between red lines at Fig. 41) (vs. $S$ adjacent to $W d$; cf. 
Figs 33-34 and 39-40). Glandular ducts $(G d)$ are much shorter than spermathecae $(S)$ (vs. Gd large, their width approximately equal to that of $S$; cf. Figs 34 and 40).

DISTRIBUTION. The Manchurian-Japanese subboreal range [Logunov, Marusik, 2001]: known from NE China and the south of Maritime Territory of Russia, eastward to the Kunashir Island and Japan, southward to Korea (Maps 1, 2).

DESCRIPTION. Male (specimen from Liaoning Prov., China). Total length 4.05. Carapace 1.87 long, 1.22 wide and 0.75 high at PLE. Ocular area: 1.07 long, 1.20 wide anteriorly and 1.23 wide posteriorly. Diameter of AME 0.42 . Clypeus 0.04 height. Chelicera length 0.38. Abdomen 2.17 long, 1.25 wide. Length of leg segments: I $1.43+1.10+$ $1.26+0.62+0.38(4.79) ;$ II $0.90+0.48+0.74+0.56+$ 0.33 (3.01); III $0.92+0.44+0.67+0.73+0.40(3.16)$; IV $1.24+0.56+1.05+1.02+0.47$ (4.34). Leg formula I, IV, III, II. Leg spination: I: Tb $5-5 \mathrm{v}$; Mt $2-2 \mathrm{v}$; remaining legs spineless. Colouration (in alcohol). General appearance as in Figs 1, 2, 5, 11. Carapace dark brown, with lots of tiny black dots and two poorly visible light brown transverse stripes (the first is situated behind eye field, the second near its posterior edge). Anterior half of eye field blackish. PLE surrounded by wide black border. Sternum uniformly yellow, with almost invisible longitudinal stripe in the middle. Endites light brown, labium yellow, with somewhat lighter inner edges. Chelicerae light brown. Dorsum dark grey, with short light brown band and a couple of round yellow spots anteriorly; more posteriorly there are three parallel strokes as an inverted $\mathrm{V}$. The second stroke widest, running to lateral sides of abdomen. Lateral sides of abdomen yellowish anteriorly and brown posteriorly. Venter yellow, with two greyish longitudinal stripes. Spinnerets light yellow. Coxae of all legs yellow. Fe I light brown, with dark grey pro- and retrolateral sides; retrolateral sides of II and III somewhat lighter; IV light brown, with greyish prolateral side. Pa I yellow, somewhat darker at its basal half; II yellow; III and IV light brown. Ti I yellow, II-IV light brown. All Mt light brown. Ta I yellow, II-IV light brown. Palp as in Figs 15-17, 21-24. Cymbium light brown anteriorly, brown posteriorly with prolateral cymbial tooth $(C t)$ directed posteriad. Tibia with RTA modified into a strong spine $(T s)$. Femur with large triangular apophysis $(\mathrm{Fa})$ on its prolateral side. Tegulum (T) large, protruding prolaterally with a membranous peak (Mtp). Embolus $(E)$ long, widened and coiled at its base. Median apophysis $(M a)$ large, complex in shape, having dorsal $(D b)$ and ventral $(\mathrm{Vb})$ branches. $\mathrm{Vb}$ flattened (Figs 23, 24), with a hook-like tip. $D b$ covered anteriorly with thin scales, having blunt anterior $(A o)$ and triangular-conical posterior outgrowth $(\mathrm{Po})$.

Female (specimen from Liaoning Prov., China). Total length 4.80. Carapace 1.99 long, 1.33 wide and 0.81 high at PLE. Ocular area: 1.17 long, 1.32 wide anteriorly and 1.34 wide posteriorly. Diameter of AME 0.46 . Clypeus 0.03 height. Chelicera length 0.44 . Abdomen 2.88 long, 1.66 wide. Length of leg segments: I $1.39+0.94+1.24+0.58+0.38(4.53)$; II $1.00+0.53+0.84+0.61+0.37(3.35) ;$ III $1.06+0.48+$ $0.83+0.83+0.39(3.59) ;$ IV $1.41+0.64+1.36+1.21+$ 0.48 (5.1). Leg formula IV, I, III, II. Leg spination: I: Tb 5$5 \mathrm{v}$; Mt 2-2v; remaining legs spineless. Colouration (in alcohol). General appearance as in Figs 3-4. Carapace as in the male but lighter. Sternum light yellow, with almost invisible longitudinal stripe in the middle and spots at its edges. Endites and labium as in the male. Chelicerae brown. Dorsum as in the male, but the second stroke interrupted in the middle. Lateral sides of abdomen yellowish anteriorly, greyish posteriorly. Ventral side of abdomen and spinnerets like in male. Legs as in the male but lighter. Epigyne as in Figs 29-34, 41. Epigyne with long converging lateral edges (Le) and large diagonal pockets $(E p)$. Anterior edge $(A e) \mathrm{U}-$ shaped, rounded or even straight ( $c f$. Figs 29, 30, 31 and 32). Ep with more or less rounded anterior groove $(A g)$, which is separated from the rest of the pocket by a couple of ridges. Copulatory openings $(\mathrm{Co})$ situated at inner edge of $A g$ (Figs 29, 33-34) and lead to long copulatory ducts $(C d)$ clearly visible even in the intact epigyne. $C d$ widened in its middle part $(W d)$, forming a large loop and strongly sclerotized curve $(S c)$ (Fig. 34, 41). Spermathecae $(S)$ oval, bearing glandular ducts $(G d)$, separated from $W d$ by a half of their diameter. Fertilization ducts $(F d)$ long and clearly visible.

NOTES. It is worth mentioning that specimens from the Russian Far East are noticeably darker than those from China, and their dorsum pattern is less contrasting (cf. Figs 1, 3 and 2,4). Moreover, males from Maritime Territory (Russia) have only four pairs of ventral spines on Tb I (Fig. 12), compared to five pairs in Chinese specimens. However, we failed to find significant differences in the structure of copulatory organs of both sexes, and thus all these specimens are treated as conspecific.

Synagelides zhilcovae Prószyński, 1979

Figs 6-10, 13-14, 18-20, 25-28, 35-40, 42, Maps 1, 2 .

Synagelides zhilcovae Prószyński, 1979: 319, figs 316-317 (+).

Synagelides zhilcovae: Peng et al., 1993: 229, figs 816-818 (+); Ono et al., 2009: 588, figs 345-346 ().

Synagelides agoriformis (nec Strand, misidentified): Prószyński, 1979: 318, figs 307-310 ( $\left.\sigma^{7}\right)$; Cho, Kim, 2002: 134, figs 86, $197\left(\sigma^{7}\right)$; Prószyński, 2009: 317, figs 38-39 $\left(\sigma^{7}\right)$; Kim, Lee, 2014: 140, fig. 99C $\left(\sigma^{7}\right)$.

For a complete list of taxonomic references see World Spider Catalog [2020].

MATERIAL. NORTH KOREA: North Pyongan Prov.: 1 व (MIZW), Myohyangsan Mt., river bank with willows and pines, 5.08.1959, B. Pisarski, J. Prószyński. — RUSSIA: Maritime Terri-

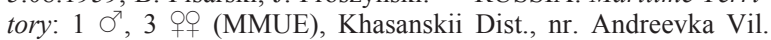
(42은 $\left.36^{\prime} \mathrm{N}, 131^{\circ} 13^{\prime} \mathrm{E}\right), 11-15.08 .1998$, Yu.M. Marusik; $1 \sigma^{\top}, 1$


29-31.07.1998, Yu.M. Marusik; 1 ○ (ISEA), Khasanskii Dist., Leopard's Land national park, downstream of Griaznaya river, nr. Reserve's cordon, broadleaf forest, litter, 25.08.2018, L.A. Trilikauskas; 1 ๆ (FEFU), nr. Il'movaya bay, oak forest, inside tent $\left(43^{\circ} 5^{\prime} 31.36^{\prime \prime} \mathrm{N}, 132^{\circ} 19^{\prime} 53.00^{\prime \prime} \mathrm{E}\right), 5.08 .2019$, M.M. Omelko; 1 우 (FEFU), Ussuriskii Dist., nr. Gornotaezhnoe Vil., Ovrazhnaya Mt. $\left(43^{\circ} 42.329^{\prime} \mathrm{N}, 132^{\circ} 07.270^{\prime} \mathrm{E}\right)$, large-block scree in the oak forest, $200 \mathrm{~m}$ a.s.1., 14.07.2019, A.A. Fomichev. Sakhalin Area: $1 \sigma^{\gamma}, 2$


$\left.61^{\prime} \mathrm{N}\right), 10-18.09 .1997$, Yu.M. Marusik. formis.

DIAGNOSIS. See above under 'Diagnosis' of S. agori-

DISTRIBUTION. The Manchurian-Japanese subboreal range [Logunov, Marusik, 2001]: known from Maritime Territory of Russia and NE China, eastward to the southern Kurile Islands and Japan, southward to Korea (Maps 1, 2). Although the exact record(s) from Japan are not shown on our map (neither they were shown by Logunov \& Marusik [2001]), S. zhilcovae is indeed listed for the Japanese fauna by Ono et al. [2009] and Ono \& Ogata [2018].

DESCRIPTION. MALE (specimen from Maritime Territory, Russia). Total length 4.59. Carapace 2.14 long, 1.44 


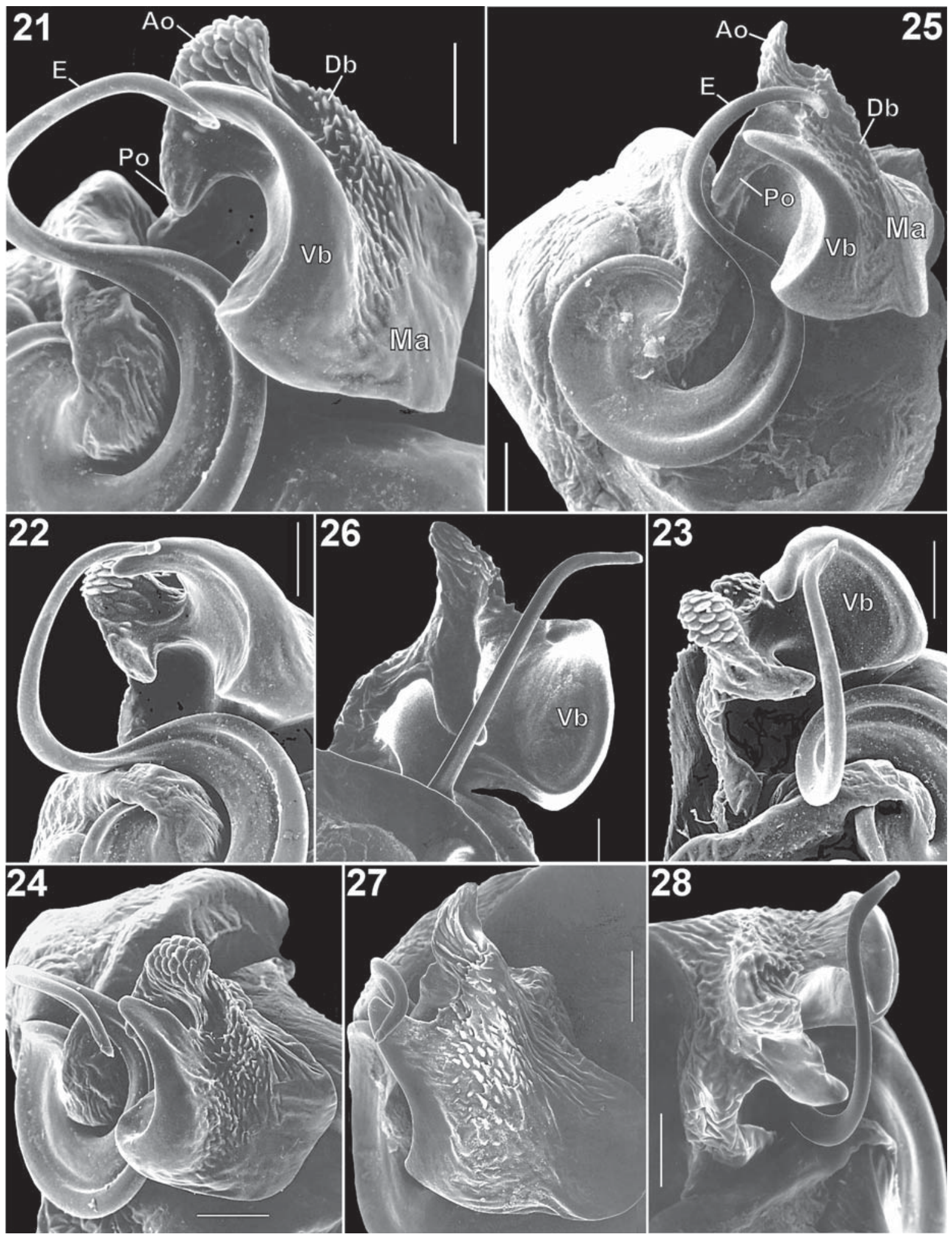

Figs 21-28. Embolic divisions of Synagelides agoriformis Strand, 1906 (21-24) and S. zhilcovae Prószyński, 1979 (25-28): 21, 25 ventral view; 22 - prolatero-ventral view; 26 - prolateral view; 23,28 - anterior view; 24,27 - anterio-dorsal view. Scale bars: 0.1 $\mathrm{mm}$. Abbreviations: Ao - anterior outgrowth; $\mathrm{Db}$ - dorsal branch, E - embolus, Ma - median apophysis, Po - posterior outgrowth, $\mathrm{Vb}$ - ventral branch.

Рис. 21-28. Эмболюсные отделы Synagelides agoriformis Strand, 1906 (21-24) и S. zhilcovae Prószyński, 1979 (25-28): 21, 25 вид вентрально; 22, 26 - вид пролатерально; 23, 28 - вид спереди; 24, 27 - вид спереди-дорзально. Масштаб 0,1 мм. Сокращения: Ao - передний вырост, Db - дорзальная ветвь, Е — эмболюс, Ма — медиальный отросток, Ро — задний вырост, $\mathrm{Vb}$ - вентральная ветвь. 


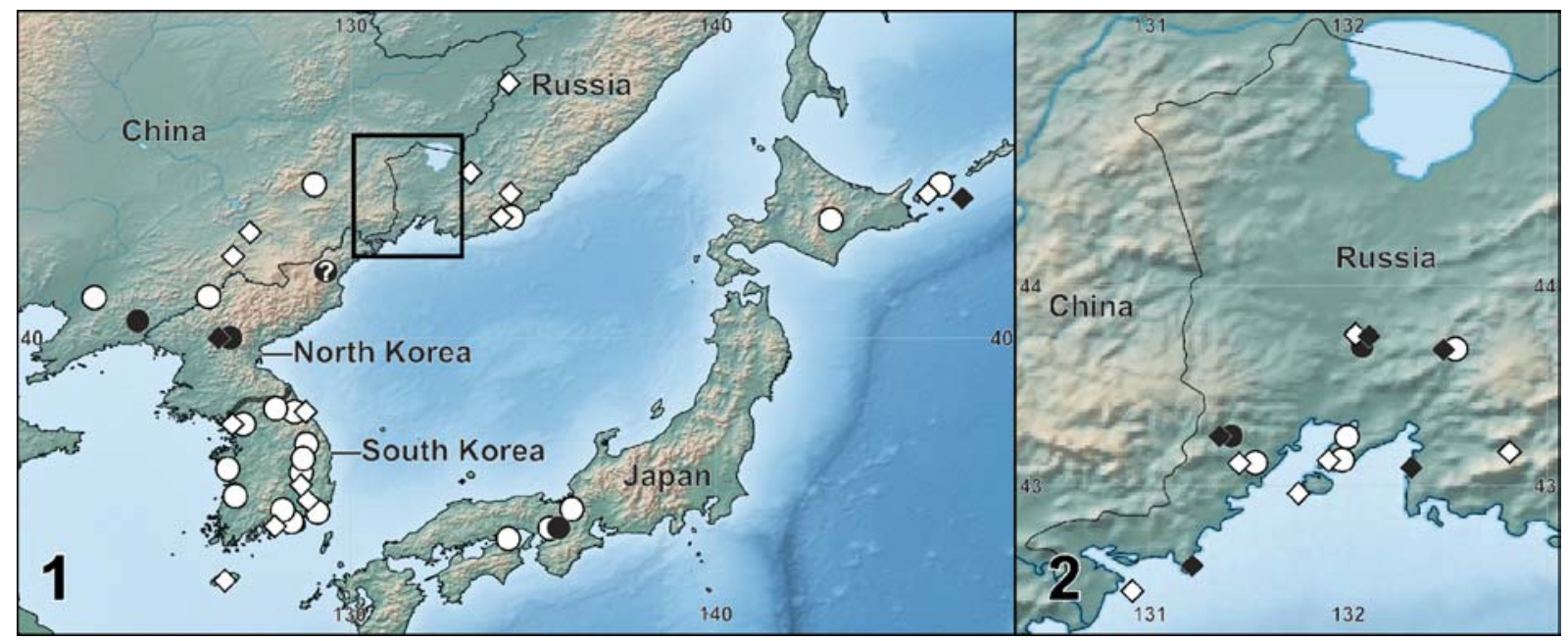

Maps 1, 2. Collecting localities of Synagelides agoriformis Strand, 1906 (circle) and S. zhilcovae Prószyński, 1979 (diamond). Black symbols refer to the studied material, white symbols refer to the literature-derived data. Question mark in circle designates an unclear locality. Some symbols on Map 1 could refer to more than one closely situated localities. The frame of Map 1 refers to the content of Map 2.

Карты 1, 2. Точки находок Synagelides agoriformis Strand, 1906 (кружок) и S. zhilcovae Prószyński, 1979 (ромб). Черные значки обозначают изученный материал, белые значки - литературные данные. Знак вопроса в кружке обозначает точку с неясным местоположением. Некоторые значки на Карте 1 могут обозначать более чем один близкорасположенный локалитет. Рамка на Карте 1 относится к содержанию Карты 2.

wide and 0.89 high at PLE. Ocular area: 1.18 long, 1.24 wide anteriorly and 1.29 wide posteriorly. Diameter of AME 0.43. Clypeus 0.05 height. Chelicera length 0.51 . Abdomen 2.45 long, 1.21 wide. Length of leg segments: I $1.76+1.39+$ $1.45+0.68+0.47(5.75) ;$ II $1.15+0.62+0.98+0.73+$ 0.40 (3.88); III $1.18+0.56+1.01+0.95+0.45$ (4.15); IV $1.52+0.69+1.38+1.28+0.52(5.39)$. Leg formula I, IV, III, II. Leg spination: I: Tb 5-5v; Mt 2-2v (Fig. 14); remaining legs spineless. Colouration (in alcohol). General appearance as in Figs 6-7, 10, 13. Carapace dark, almost black, with dark brown triangular area behind eye field. Eye field black. Sternum light brown, with darker edges and a poorly visible longitudinal stripe in the middle. Endites and labium brown, with yellow inner edges. Chelicerae light brown, yellowish near fang. Dorsum blackish, with a couple of light brown spots anteriorly; in some specimens these spots poorly visible (cf. Figs 6 and 7). There are three narrow, yellow strokes in the posterior half of dorsum: the first of them transverse, while others as an inverted V. Lateral sides of abdomen dark grey, with yellow stripes. Venter yellowish anteriorly and greyish posteriorly. Spinnerets dark brown. Coxae of all legs yellow. Fe I dark brown, prolateral side yellowish apically; II, III yellow, with black prolateral side; IV brown with black prolateral side. Pa I light brown basally and yellowish apically; II-IV light brown with grayish proand retrolateral sides. Ti I light brown; II, III light brown with somewhat darker pro- and retrolateral sides; IV brown with grayish pro- and retrolateral sides. Mt I-IV light brown. Ta I yellowish; II-IV light brown. Palp as in Figs 18-20, 25-28. Cymbium light brown anteriorly, brown posteriorly with large, flattened prolateral cymbial tooth $(C t)$ going in posterior and dorsal direction. Tibia with RTA modified into strong spine $(T s)$. Femur prolaterally with large triangular apophysis $(F a)$. Tegulum $(T)$ large, protruding prolaterally with a pointed membranous peak $(M t p)$. Embolus $(E)$ as in $S$. agorifirmis: long, widened and coiled at its base. Median apophysis $(M a)$ large, with two branches: dorsal $(D b)$ and ventral $(V b) . V b$ flattened (Figs 26, 27), with a hook-like tip well visible retrolaterally (Fig. 20). $D b$ covered anteriorly with small scales, having two outgrowths: thin, pointed anterior $(A o)$ and more rounded posterior $(P o)$.

Female (specimen from Maritime Territory, Russia). Total length 5.09. Carapace 2.15 long, 1.36 wide and 0.84 high at PLE. Ocular area: 0.98 long, 1.28 wide anteriorly and 1.36 wide posteriorly. Diameter of AME 0.44. Clypeus 0.03. Chelicera length 0.45 . Abdomen 2.94 long, 1.53 wide. Length of leg segments: I $1.34+0.86+1.20+0.56+0.40(4.53)$; II $1.03+0.50+0.83+0.64+0.35(3.35) ;$ III $1.06+0.49+$ $0.90+0.86+0.46(3.59) ;$ IV $1.33+0.69+1.40+1.25+$ 0.54 (5.21). Leg formula IV, I, III, II. Leg spination: I: Tb 5$5 \mathrm{v}$; Mt 2-2v; remaining legs spineless. Colouration (in alcohol). General appearance as in Figs 8, 9. Carapace as in the male. Sternum yellow, with wide black edges and a thin longitudinal stripe. Endites and labium black, with yellow inner edges. Chelicerae dark brown, lighter near fangs. Dorsum as in the male, but strokes thinner and more numerous (about six). Lateral sides black, with thin yellow stripes. Venter dark grey, with four longitudinal lines consisting of tiny yellow spots. Spinnerets black. Legs colouration as in the male but significantly more contrasting. Segment sides which are grey in the males are black in the females. Epigyne as in Figs 35-40, 42. Epigyne with long converging lateral edges $(L e)$ and large diagonal pockets $(E p)$. Anterior edge ( $A e$ ) V-shaped, its shape varies (cf. Figs 35-38). Ep with large, rounded or oval anterior groove $(A g)$ and small posterior groove $(\mathrm{Pg}) . \mathrm{Ag}$ separated from the rest of pocket by a single ridge. Copulatory openings $(\mathrm{Co})$ situated at inner edge of $A g$ (Figs 35, 39-40), leading to long copulatory ducts $(C d)$. $C d$ widened in its middle part $(W d)$, forming a large loop and a strongly sclerotized curve $(S c)$ (Fig. 40, $42)$. Spermathecae $(S)$ oval, located very close to $W d$ and bear very long glandular duct $(G d)$. Fertilization ducts $(F d)$ short and poorly visible. 

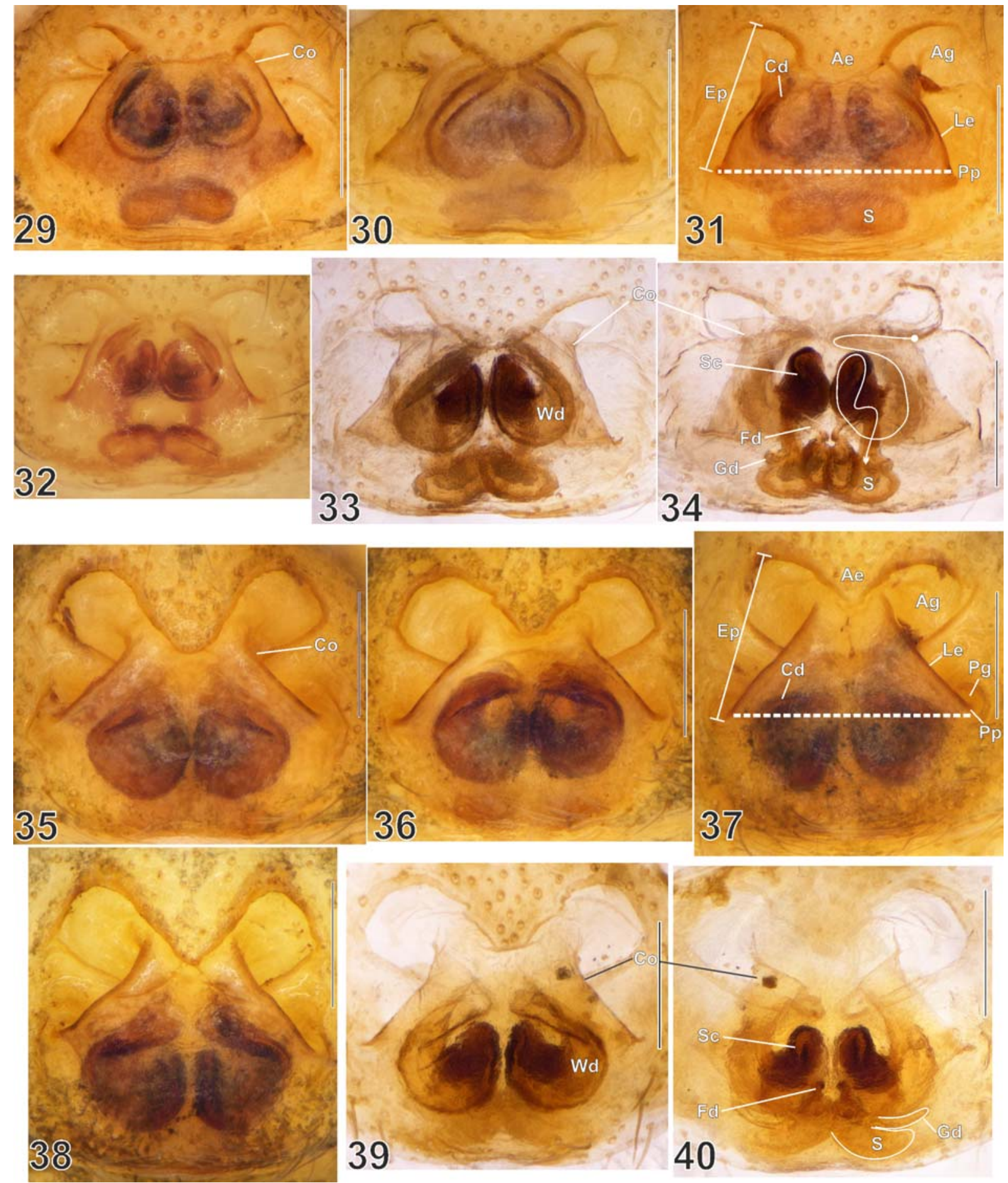

Figs 29-40. Epigyne of Synagelides agoriformis Strand, 1906 (29-34) and S. zhilcovae Prószyński, 1979 (35-40): 29-32, 35-38 intact epigyne, ventral view; 33, 39 - macerated epigyne, ventral view; 34, 40 - macerated vulva, dorsal view. Scale bars: $0.2 \mathrm{~mm}$. Abbreviations: $\mathrm{Ae}$ - anterior edge of epigyne, $\mathrm{Ag}$ — anterior groove of epigyne pocket, $\mathrm{Cd}$ - copulatory duct, $\mathrm{Co}$ — copulatory opening, $\mathrm{Ep}$ - pocket of epigyne, $\mathrm{Fd}$ - fertilization duct, $\mathrm{Gd}$ - glandular duct, Le - lateral edge of epigyne, $\mathrm{Pg}$ - posterior groove of epigyne pocket, $\mathrm{Pp}$ - posterior edge of epigyne pocket, S - spermathecae, Sc — sclerotized curve of copulatory ducts, Wd — widened part of copulatory duct.

Рис. 29-40. Эпигина Synagelides agoriformis Strand, 1906 (29-34) и S. zhilcovae Prószyński, 1979 (35-40): 29-32, 35-38 интактная эпигина, вид вентрально; 33, 39 - мацерированная эпигина, вид вентрально; 34, 40 - мацерированная вульва, вид дорсально. Масштаб 0,2 мм. Сокращения: Ae - передний край эпигины, Ag - переднее углубление кармана эпигины, Сd копулятивный канал, Со - копулятивное отверстие, Еp — карман эпигины, $\mathrm{Fd}$ - оплодотворительный канал, $\mathrm{Gd}$ - железистый канал, Le - латеральный край эпигины, Pg - заднее углубление кармана эпигины, Pp — задний край кармана эпигины, S сперматека, $\mathrm{Sc}$ - склеротизованный изгиб копулятивного канала, $\mathrm{Wd}$ - расширенная часть копулятивного канала. 

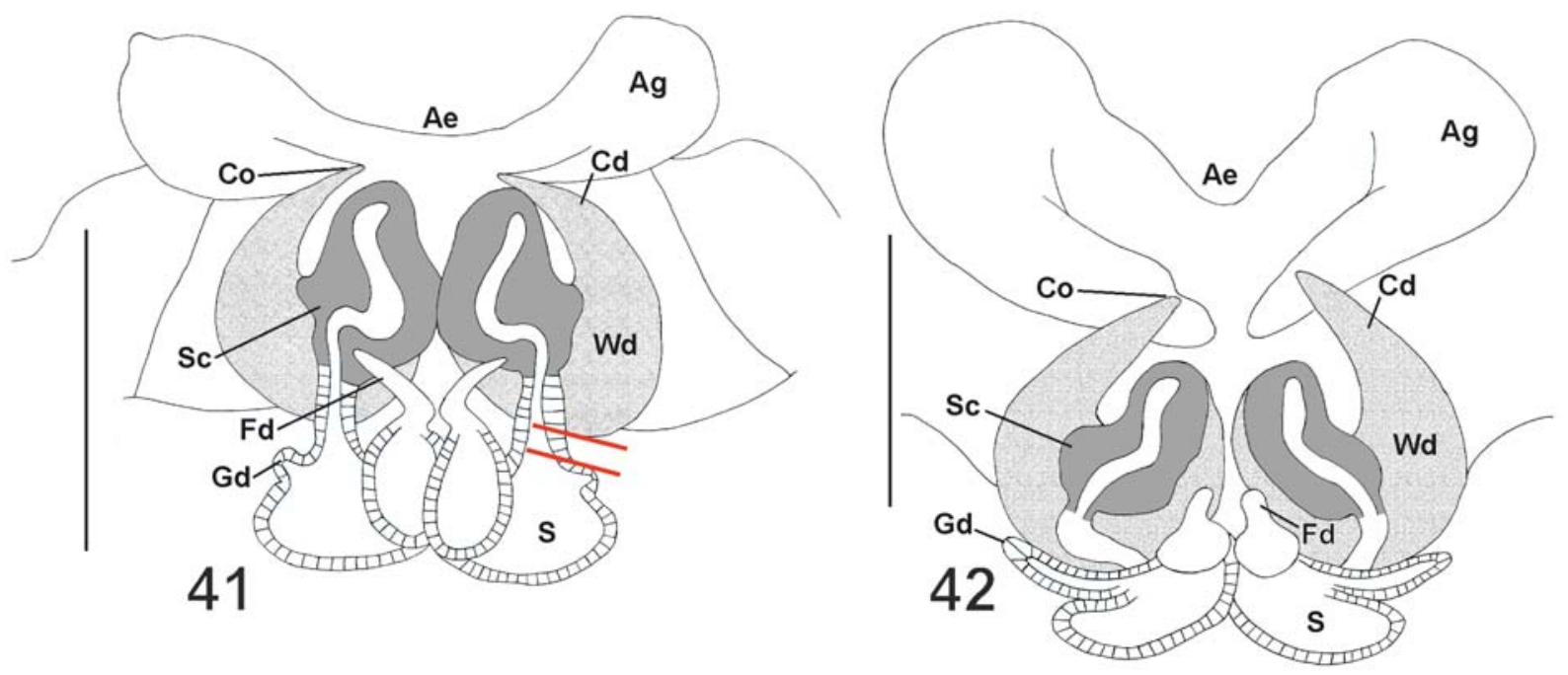

Figs 41-42. Vulva of Synagelides agoriformis Strand, 1906 (41) and S. zhilcovae Prószyński, 1979 (42). Scale bars: $0.2 \mathrm{~mm}$. Abbreviations: $\mathrm{Ae}$ - anterior edge of epigyne; $\mathrm{Ag}$ — anterior groove of epigyne pocket, $\mathrm{Cd}$ - copulatory duct, $\mathrm{Co}$ - copulatory opening, $\mathrm{Fd}$ - fertilization duct, Gd - glandular duct, S - spermathecae, Sc — sclerotized curve of copulatory ducts, Wd — widened part of copulatory duct.

Figs 41-42. Вульвы Synagelides agoriformis Strand, 1906 (41) и S. zhilcovae Prószyński, 1979 (42). Масштаб 0,2 мм. Сокращения: $\mathrm{Ae}$ - передний край эпигины, $\mathrm{Ag}$ - переднее углубление кармана эпигины, $\mathrm{Cd}$ - копулятивный канал, $\mathrm{Co}$ - копулятивное отверстие, $\mathrm{Fd}$ - оплодотворительный канал, $\mathrm{Gd}$ - железистый канал, $\mathrm{S}$ - сперматека, $\mathrm{Sc}$ — склеротизованный изгиб копулятивного канала, Wd - утолщенная часть копулятивного канала.

\section{Discussion}

Both species belongs to the agoriformis species group (sensu Bohdanowicz [1979]) and are closely related. The similarity between them has led to the confusion with regards to their males and females being misidentified and published under mistaken names. The male of $S$. zhilcovae, which is considered undescribed [WSC, 2020], has been repeatedly presented as $S$. agoriformis (see above under the synonymy list). Besides the similarity in general appearances, the problem is aggravated by the fact that the body colouration of $S$. agoriformis and the female copulatory organs of both species are subject to a strong variation. Moreover, both species co-exist in exactly the same biotopes, such as leaf litter of deciduous forests or screes. In their body shape, $S$. agoriformis and S. zhilcovae (like all other congeners) resemble ants. Some specimens from Japan were collected from near ant nests [Bohdanowicz, 1979]. However, to date the relationships between these species and ants remain unstudied.

Acknowledgments. We thank M.M. Omelko senior (Gornotaezhnoe, Russia) for his help with organizing the fieldtrip to Maritime Territory of Russia, during which the part of material treated here was collected. We are grateful to D.V. Logunov (Manchester, UK) for providing SEM micrographs, commenting on the early draft and editing the final version of the manuscript.

\section{References}

Bohdanowicz A. 1979. Descriptions of spiders of the genus Synagelides (Araneae: Salticidae) from Japan and Nepal // Acta Arachnologica. Vol.28. No.2. P.53-62.

Bohdanowicz A., Prószyński J. 1987. Systematic studies on East Palaearctic Salticidae (Araneae), IV. Salticidae of Japan // Annales Zoologici, Warszawa. Vol.41. No.2. P.43-151.

Chikuni Y. 1989. Pictorial encyclopedia of spiders in Japan. Kaisei-sha Publishing Co., Tokyo. 310 pp.

Cho J.H., Kim J.P. 2002. A revisional study of family Salticidae Blackwall, 1841 (Arachnida, Araneae) from Korea // Korean Arachnology. Vol.18. No.2. P.85-169.

Kanesharatnam N., Benjamin S.P. 2020. First record of Synagelides Strand, 1906 (Araneae: Salticidae) from Sri Lanka: description of four endemic species from tropical wet forest of the island // Zootaxa. Vol.4790. No.1. P.43-56.

Kim J.H., Kim J.P. 2003. The comparative study of salticid spiders and ants inferred from morphology // Korean Arachnology. Vol.19. No.2. P.133-154

Kim S.T., Lee S.Y. 2014. Arthropoda: Arachnida: Araneae: Clubionidae, Corinnidae, Salticidae, Segestriidae. Spiders // Invertebrate Fauna of Korea. Vol.21. No.31. P.1-186.

Logunov D.V. 2017. New species and records in the genus Synagelides Strand in Bösenberg et Strand, 1906 (Aranei: Salticidae) from the Oriental region // Arthropoda Selecta. Vol.26. No.4. P.315-322.

Logunov D.V., Hereward J. 2006. New species and synonymies in the genus Synagelides Strand in Bösenberg \& Strand, 1906 (Araneae: Salticidae) // Bulletin of the British Arachnological Society. Vol.13. Pt.13. P.281-292.

Logunov D.V., Marusik Yu.M. 2001. Catalogue of the jumping spiders of northern Asia (Arachnida, Araneae, Salticidae). Moscow: KMK Scientific Press. 300 pp.

Namkung J. 2002. The spiders of Korea. Seoul: Kyo-Hak Publishing Co. 648 pp.

Ono H., Ikeda H., Kono R. 2009. Salticidae // Ono H. (ed.). The spiders of Japan with keys to the families and genera and 
illustrations of the species. Tokai University Press, Kanagawa. P.558-588.

Ono H., Ogata K. 2018. Spiders of Japan: their natural history and diversity. Kanagawa: Tokai University Press. 714 pp.

Peng X.J., Xie L.P., Xiao X.Q., Yin C.M. 1993. Salticids in China (Arachnida: Araneae). Hunan Normal University Press, 270 pp.

Prószyński J. 1979. Systematic studies on East Palearctic Salticidae III. Remarks on Salticidae of the USSR // Annales Zoologici, Warszawa. Vol.34. No.11. P.299-369.

Prószyński J. 2009. Comments on the Oriental genera Agorius and Synagelides (Araneae: Salticidae) // Makarov S.E., Dimitrijević R.N. (eds.). Advances in arachnology and developmental biology. Institute of Zoology, Bulgarian Academy of Sciences Monographs. Vol.12. P.311-325.

Prószyński J. 2017. Pragmatic classification of the world's Salticidae (Araneae) // Ecologica Montenegrina. Vol.12. P.1-133. Song D.X., Zhu M.S., Chen J. 1999. The spiders of China. Shijiazhuang: Hebei Science and Technology Publishing House. 640 pp.

World Spider Catalog. 2020. World Spider Catalog. Version 21.5. Natural History Museum Bern, online at http://wsc.nmbe.ch (accessed on September 2020)

Responsible editor D.V. Logunov 